\title{
DEFERENCE DEFERRED: THE SUBVERSION OF THE DEFERENCE RULE IN PENNSYLVANIA IN VIEW OF THE UNITED STATES SUPREME COURT'S RECENT DECISION IN HOSANNA-TABOR
}

\author{
Katherine L. Pomerleau*
}

In a landmark 1872 decision, the United States Supreme Court in Watson v. Jones adamantly rejected the firmly established English precedent that allowed civil courts to make extensive judgments regarding the correctness of a religious organization's theological beliefs in order to resolve ecclesiastical property controversies. ${ }^{1}$ The Court instead established what is now called the "deference rule" to facilitate the resolution of ecclesiastical property disputes while respecting the right of religious organizations to make decisions regarding their own governance, discipline, and doctrines. ${ }^{2}$ The Watson Court based its decision on the principle of religious freedom underlying the United States' novel First Amendment Free Exercise Clause. ${ }^{3}$ The Supreme Court later qualified the

\footnotetext{
* University of Pittsburgh School of Law, J.D. May 2012; Franciscan University of Steubenville, M.A. 2009; St. Vincent College, B.A. 2007. I would like to express my gratitude to all who assisted and encouraged me with all phases of this project. Thanks are due especially to Professor Arthur Hellman, who alerted me to the Hosanna-Tabor decision and provided much-needed feedback regarding my analysis of that case. Lastly, I would like to thank my family, especially Mark Pomerleau, who analyzed numerous drafts and helped me to define the big picture. Any remaining errors are my own.

${ }^{1}$ See Watson v. Jones, 80 U.S. 679, 727-28 (1871) (rejecting the English precedent set forth by Lord Eldon in Attorney-General v. Pearson, 3 Merivale 353 and Craigdallie v. Aikman, 2 Bligh 529).

${ }^{2} I d$. at $732-33$. The Court held that where a religious organization had created a tribunal with the power to decide the controversy and where the subject-matter of the property dispute involved "theological controversy, church discipline, ecclesiastical government, or the conformity of the members of the church to the standard of morals required of them," that the decision of the highest ecclesiastical tribunal is final. $I d$. at 733 .

${ }^{3} I d$. at 728 . The Watson Court explained their dissention by differentiating between the two nations' forms of government. England, the Court explained, had "[1]aws ... hampering the free exercise of
} 
deference rule in 1969 with the concept that some ecclesiastical property disputes may be decided with neutral principles of law, i.e. principles that do not embroil the court in substantive religious determinations. ${ }^{4}$ Courts vary in the manner in which these tests are applied, however, resulting in some cases in an erosion of the First Amendment protections that these tests offer to religious organizations. This article will explore this phenomenon in Pennsylvania state courts, focusing specifically on the Pennsylvania Supreme Court's 2009 decision in Connor v. Archdiocese of Philadelphia. ${ }^{5}$ In Connor, the Pennsylvania Supreme Court dictated an element-by-element application of the "neutral principles" analysis prior to and instead of the application of the deference rule, which effectively subverts the use of the deference rule and thereby undermines the First Amendment inquiry necessary to guard the freedom of religious organizations. ${ }^{6}$

In this article, I contend that the Pennsylvania Supreme Court in Connor failed to distinguish between the functions of the neutral-principles analysis and the deference rule. That is, Connor's interpretation of the appropriate use of neutralprinciples analysis asks only whether a controversy may be addressed by a court without excessive entanglement in religious dogma or doctrine. This understanding of the appropriate inquiry omits any consideration of the religious organization's right to religious freedom - the Connor test asks if a court can decide the issue and does not ask whether a court should decide it. This disregard for the rights of religious organizations flies in the face of longstanding Supreme Court precedent of firmly upholding the First Amendment religion clauses, most recently reaffirmed by the Court in its January 2012 decision in Hosanna-Tabor Evangelical Lutheran Church v. EEOC. ${ }^{7}$

In examining this complex issue, Section I of this article supplies background information regarding the origin and application of the deference rule and the

religious belief and worship in many most impressive forms," while the United States espoused the "full and free right to entertain any religious belief, to practice any religious principles ...." Id.

${ }^{4}$ See Presbyterian Church in the United States v. Mary Elizabeth Blue Hull Mem'l Presbyterian Church, 393 U.S. 440 (1969), in which the Court first articulated the neutral principles approach. "[N]ot every civil court decision as to property claimed by a religious organization jeopardizes values protected by the First Amendment ... there are neutral principles of law, developed for use in all property disputes, which can be applied without 'establishing' churches to which property is awarded." Id. at 449. See also Jones v. Wolf, 443 U.S. 595 (1979); Serbian Eastern Orthodox Diocese for the United States and Canada v. Milivojevich, 426 U.S. 696 (1976).

${ }^{5} 975$ A.2d 1084 (Pa. 2009).

${ }^{6} I d$.

${ }^{7} 132$ S. Ct. 694 (2012). 
neutral-principles analysis. Section II analyzes the Connor Court's formulation of the deference and neutral-principles analyses. Section III focuses on Pennsylvania lower courts' subsequent application of Connor's precedent. Section IV discusses the United States Supreme Court's recent decision in Hosanna-Tabor and how its approach to the First Amendment religion clauses demonstrates that the Connor Court's test lacks an important constitutional inquiry necessary to safeguard the freedom of religious organizations. Ultimately, the Hosanna-Tabor decision demonstrates the U.S. Supreme Court's dedication to upholding the purpose of ensuring religious freedom to religious organizations that underlies the First Amendment religion clauses. In addition, a comparison between Connor and Hosanna-Tabor demonstrates how Connor's element-by-element application of the neutral-principles analysis prior to any deference considerations effectively omits this constitutional inquiry, severely curtailing the constitutional rights of religious organizations in Pennsylvania.

\section{BACKGROUND INFORMATION: THE DEFERENCE RULE AND NeUTral-Principles ANALYSIS}

\section{A. The Deference Rule}

In 1872, the United States Supreme Court first articulated the right of religious organizations to control certain aspects of their internal affairs-the foundation for the deference rule ${ }^{8}$-in Watson v. Jones. ${ }^{9}$ Watson involved a property dispute between pro-slavery and anti-slavery factions of the Presbyterian Church after the end of the Civil War. ${ }^{10}$ Each faction claimed that the election of its opposing faction's elders was invalid, that its own faction should be recognized as the valid local church, and that it was therefore the rightful owner of the local church building. ${ }^{11}$ While the Watson Court ultimately decided the controversy against the separated faction because of the peculiarities of the facts at hand, ${ }^{12}$ it

${ }^{8}$ This article contains only a brief survey of the history of the deference rule and neutral principles analysis for background purposes. For a fuller discussion of the deference rule, see, among other sources, Roland F. Chase, Annotation, Determination of Property Rights Between Local Church and Parent Church Body: Modern View, 52 A.L.R.3d 324 (2011); Scott C. Idleman, Tort Liability, Religious Entities, and the Decline of Constitutional Protection, 75 IND. L.J. 219, 220-27 (2000).

${ }^{9} 80$ U.S. 679 (1871).

${ }^{10} I d$. at 717 .

${ }^{11} I d$.

${ }^{12}$ Id. at 734-35. In Watson, the appellants in the case before the Supreme Court had admittedly separated from the national Presbyterian Church, set up an opposing church, denied the authority of the national Presbyterian Church, and refused to abide by its judgments. By their actions, the appellants 
first laid the foundation for what would become the constitutional inquiry known as the deference rule. ${ }^{13}$

The first formulation of this doctrine specified that whenever the highest applicable church tribunal has decided "questions of discipline, or of faith, or ecclesiastical rule, custom, or law," civil courts must accept these decisions as final and binding. ${ }^{14}$ The Watson Court articulated three distinct rationales behind its rule. It argued that civil court intrusion into these areas violates the rights of religious organizations to practice their religion by subverting the authority of the religious tribunals established to resolve such religious issues. ${ }^{15}$ The Watson Court understood this self-determinative aspect of religious institutions to be a fundamental aspect of religious freedom. ${ }^{16}$ In addition, the Court emphasized the voluntary nature of joining oneself to a religious body and the implied consent to be bound by the government of such bodies once joined. ${ }^{17}$ Lastly, the Court argued that civil courts lack the competency to address the intricacies of ecclesiastical law and religious faith, and should thus defer to the "more learned tribunal."18

While the Watson Court analysis had an arguably constitutional ring, it was in 1952 that the Supreme Court explicitly tied the deference rule to the First Amendment in Kedroff v. St. Nicholas Cathedral. ${ }^{19}$ The Court struck down a

have effectively declared that they are not the faction in line with the national Presbyterian Church, and therefore have no arguable right to the church property. Id.

${ }^{13}$ Id. at $726-34$.

${ }^{14}$ Id. at 727 .

${ }^{15} I d$. at 729 .

16 Id. This concept of a religious decision-making body being free from civil law determinations arguably stems from the theological concept in place at the time of the Founders and authors of the First Amendment that religion, far from being a set of rituals or customs, was the expression of duty that each individual owes her creator. This duty and the laws that accompanied it were considered to exist at a more fundamental level than civil law. Thus, civil law could not bind religious law or an individual's conscience. See JeFFrey A. Brauch Et AL., A Higher LAW: READINGS ON THE INFLUENCE OF Christian Thought in Anglo-American Law (William S. Hein \& Co., Inc. 2d ed. 2008). See also The Free Exercise of Religion Clause (The First Amendment): Its COnstitutional History AND THE CONTEMPORARY DEBATE (Thomas C. Berg ed., 2008) [hereinafter THE FREE EXERCISE OF RELiGiOn CLAUSE].

${ }^{17}$ Watson, 80 U.S. at 729.

${ }^{18} I d$.

${ }^{19}$ See Kedroff v. St. Nicholas Cathedral of Russian Orthodox Church in North America, 344 U.S. 94 (1952). Watson was decided before the Fourteenth Amendment applied the First Amendment to the states, so, although Watson framed its discussion in constitutional terms, the deference rule did not explicitly rely on the First Amendment until Kedroff. See id. 
statute passed by the New York State Legislature that recognized the administrative autonomy of the Russian Orthodox churches located in North America from the general Russian Orthodox Church located in the Soviet Union. ${ }^{20}$ Notably, the Kedroff Court quoted extensively from the Watson opinion and asserted only that the Watson rule was now a constitutional argument; the Kedroff Court did not change the formulation of, or the rationale for, the deference rule. ${ }^{21}$ The deference rule as articulated by the United States Supreme Court has been adopted by the Pennsylvania Supreme Court, which participates in this deference-rule tradition. ${ }^{22}$

\section{B. The Neutral-Principles Analysis}

In an attempt to articulate which ecclesiastical property disputes could be adjudicated by civil courts, the Court first described the neutral-principles doctrine in Presbyterian Church in the U.S. v. Mary Elizabeth Blue Hull Memorial Presbyterian Church. ${ }^{23}$ The Mary Elizabeth Court declined to resolve a property dispute which would have required a determination of whether the national Presbyterian Church had substantially departed from the tenets of Presbyterianism. ${ }^{24}$ The Court founded its ruling on the deference rule as articulated in the Watson and Kedroff opinions, which it analyzed extensively. ${ }^{25}$ However, the Court went on to articulate what became known as the neutral-principles doctrine, stating that since not all disputes involving religious organizations require the determination of religious issues for their resolution, "there are neutral principles of law, developed for use in all property disputes, which can be applied without

\footnotetext{
${ }^{20} I d$. at 119 (arguing that the New York State legislature by its actions intruded into the "forbidden area of religious freedom contrary to the principles of the First Amendment").

${ }^{21} I d$. at $115-16$.

${ }^{22}$ See, e.g., German Reformed Church v. Seibert, 3 Pa. 282 (Pa. 1846); Irvine v. Elliott, 55 A. 859 (Pa. 1903); Heil v. Stauffer, 137 A.2d 179 (Pa. 1927). Most recently, the Pennsylvania Supreme Court applied the deference rule in In re Church of St. James the Less, 888 A.2d 795 (Pa. 2005). German Reformed Church predates Watson and was actually cited in that opinion as support for the Supreme Court's adoption of a deference rule. Watson v. Jones, 80 U.S. 679, 732 (1871). Since the Pennsylvania Supreme Court adopts (although chooses in that case not to apply) the Watson deference rule in Presbytery of Beaver-Butler of the United Presbyterian Church in the United States v. Middlesex Presbyterian Church, 489 A.2d 1317, 1320 (Pa. 1985), this article will limit its discussion to later Pennsylvania cases involving the deference rule.

${ }^{23} 393$ U.S. 440, 449 (1969). The Mary Elizabeth Court did not apply the neutral principles approach. Rather, that Court resolved the issue using the deference rule. See id.

${ }^{24}$ Id. at 447 .

${ }^{25}$ See id. at $445-49$.
} 
'establishing' churches to which property is awarded." 26 In effect, the Mary Elizabeth Court formed the neutral-principles analysis as a post-deference inquiry. That is, once a court has determined that the resolution of the issue would not infringe on the organization's First Amendment rights, it may then engage in a neutral-principles analysis. If there are neutral principles of law with which the court may decide the issue, then the court may do so.

The U.S. Supreme Court in Jones v. Wolf conducted a neutral-principles analysis and articulated its rationale for doing so. ${ }^{27}$ The Jones Court accepted Mary Elizabeth's assertion that not all church property disputes required constitutionally impermissible inquiries into issues of religious doctrine or polity. ${ }^{28}$ In instances where the First Amendment religion clauses did not mandate deference, the Jones Court concluded that the application of the neutral-principles analysis was both permissible and advantageous. ${ }^{29}$ The Jones Court lauded the neutral-principles approach as a test that relied completely on "objective, well established concepts ... of law familiar to lawyers and judges." ${ }^{30}$ The Court felt that this test would "free civil courts completely from entanglement in questions of religious doctrine, polity, and practice." ${ }^{31}$ The deference rule, however, remains an integral part of the neutral-principles inquiry as a preliminary determination of whether the court would have to resolve church property suits on the basis of religious doctrine or practice. $^{32}$

\footnotetext{
${ }^{26} I d$. at 449 .

${ }^{27} 433$ U.S. 595 (1979).

${ }^{28} I d$. at 602 .

${ }^{29} I d$. at $602-03$.

${ }^{30} I d$. at 603 .

${ }^{31} I d$.
}

${ }^{32} I d$. at 602 . Pennsylvania courts adopted and consistently applied the neutral principles analysis as articulated in Jones v. Wolf. See Presbytery of Beaver-Butler of the United Presbyterian Church in the U.S. v. Middlesex Presbyterian Church, 489 A.2d 1317 (Pa. 1985); St. Michael \& Archangel Russian Orthodox Greek Catholic Church v. Uhniat, 301 A.2d 655 (Pa. 1973); W. Pa. Conference of the United Methodist Church v. Everson Evangelical Church of N. Am., 312 A.2d 35 (Pa. 1973); Conference of African Union First Colored Methodist Protestant Church v. Shell, 659 A.2d 77 (Pa. Commw. Ct. 1995); Orthodox Church of Am. v. Pavuk, 538 A.2d 632 (Pa. Commw. Ct. 1988); Bd. of Bishops of the Church of the Living God v. Milner, 513 A.2d 1131 (Pa. Commw. Ct. 1986); Mikilak v. Orthodox Church in Am., 513 A.2d 541 (Pa. Commw. Ct. 1986); Presbytery of Donegal v. Calhoun, 513 A.2d 531 (Pa. Commw. Ct. 1986); Presbytery of Donegal v. Wheatley, 513 A.2d 538 (Pa. Commw. Ct. 1986). 


\section{ConNor V. ARCHDiocese of PHILADELPHIA}

The Pennsylvania Supreme Court in Connor v. Archdiocese of Philadelphia ${ }^{33}$ interpreted and applied the neutral-principles analysis in a way that subverts the preliminary application of the deference rule. The Connor Court's insistence on an element-by-element application of the neutral-principles analysis prior to the application of the deference rule leads to severe infringement of the First Amendment rights of religious organizations in Pennsylvania.

\section{A. Factual Background}

Connor involved claims of defamation and intentional and negligent infliction of emotional distress brought by the Connors against St. Eleanor's School and the Diocese of Philadelphia upon their son Eric's expulsion for allegedly bringing a weapon to school. ${ }^{34}$ After reading The Outsiders, a book which the Connors alleged contains gratuitous gang violence, Eric and his male classmates in the seventh grade at St. Eleanor's School, a Roman Catholic elementary school, developed "a significant interest in knives and weapons. ${ }^{35}$ During an ongoing recess feud between the sixth- and seventh-grade boys, Eric got into a shoving match with one of the sixth-grade boys, and the two groups subsequently arranged a "rumble" for the next day. ${ }^{36}$ Eric allegedly told a classmate that he intended to bring in something that would not do any damage but that would make a good bluff. ${ }^{37}$ The following day, school administration called Eric to the principal's office and discovered in Eric's possession a kit containing a two-inch nail file, scissors, and a letter opener. ${ }^{38}$ Eric was subsequently expelled for bringing a "weapon" to school, and the school administration circulated a letter stating that a student brought a "penknife" to school and had been expelled. ${ }^{39}$ The Connors alleged that the school

\footnotetext{
33975 A.2d 1084 (Pa. 2009).

${ }^{34} I d$. at 1085 .

${ }^{35}$ Id. at 1086 .

${ }^{36} \mathrm{Id}$.

${ }^{37} \mathrm{Id}$.

${ }^{38} I d$.

${ }^{39} I d$.
} 
also made defamatory post-expulsion oral remarks to individual parents that implied that Eric posed a threat to the school and community. ${ }^{40}$

The Connors contended that the Pennsylvania Supreme Court should be able to resolve the issues involved in their tort case because the question of whether the school made false statements about Eric were issues that could be resolved by applying neutral principles of tort law. ${ }^{41}$

Without first conducting a deference rule inquiry, the Court decided that a neutral-principles analysis was proper, ${ }^{42}$ since the Connors did not challenge the expulsion decision but instead sought damages for communications that the School allegedly made subsequent to Eric's expulsion. ${ }^{43}$ The Court determined that it was "reasonably likely that the trial court will ultimately be able to consider whether the parties carried their respective burdens as to each element of appellants' defamation claims without intruding into the "sacred precincts.",44

\section{B. The Connor Court Reverses the Application of the Neutral- Principles Analysis and the Deference Rule}

When the Connor Court articulated the neutral-principles analysis in its opinion, it actually described a new interpretation of the analysis that placed it before the deference-rule determination. The Court stated that

[T]he fact-finding court must: (1) examine the elements of each of the plaintiff's claims; (2) identify any defenses forwarded by the defendant; and (3) determine whether it is reasonably likely that, at trial, the fact-finder would ultimately be able to consider whether the parties carried their respective burdens as to every element of each of the plaintiff's claims without "intruding into the sacred precincts," Beaver-Butler, 489 A.2d at $1321 .^{45}$

\footnotetext{
${ }^{40} I d$. at 1087-88. The Connors alleged that the items found with Eric did not constitute "weapons," and that the letters and oral communications therefore involved untrue and harmful statements about their son. Id.

${ }^{41} I d$. at $1097-98$.

${ }^{42}$ The breadth of the neutral principles analysis - whether it is a proper inquiry in tort claims - was at issue in Connor and remains a legitimate issue in Pennsylvania. This issue, however, is not addressed in the scope of this article.

${ }^{43}$ Connor, 975 A.2d at 1101.

${ }^{44} I d$. at 1113.

${ }^{45} I d$. at 1103 .
} 
The Court called for a "claim-by-claim, element-by-element approach,",46 noting that, only if it seemed likely that the parties could not carry their burdens without offering impermissible religious evidence, should the deference rule be applied. $^{47}$

Applying this new interpretation of the neutral-principles analysis, the Connor Court listed the seven elements of defamation, noting that the only contested element in the defamation claim was the defamatory nature of the post-expulsion communications, that is, whether any of the items that Eric brought to school could fairly be described as a "weapon" and a "pen-knife." 48 Ultimately, the Court held that the question of whether the Eric's items could be classified as weapons was "a secular finding of fact well within the ken of a fact-finding civil court," and, therefore, that those neutral principles of law could be applied to determine whether the post-expulsion communications were defamatory. ${ }^{49}$

\section{The Effect of the New Application of the Neutral-Principles Analysis on the Deference Rule}

While praising the wisdom of and purporting to uphold the deference rule in its opinion, the Connor Court's articulation of its new neutral-principles analysis weakened and ultimately usurped the role of the deference rule. The deference rule and the neutral-principles analysis coexisted in the past, and the function of the neutral-principles analysis had always been to serve as a method to resolve church property disputes that a court had already determined (using the deference rule) did not involve religious doctrine or discipline, etc. ${ }^{50}$ The deference rule (i.e. the constitutional inquiry) was always the first step in the decision of whether a court should engage in a neutral-principles analysis. ${ }^{51}$ The neutral-principles analysis was merely one way of resolving those few cases that were not "severely circumscribe[d]" from civil court review by the First Amendment. ${ }^{52}$

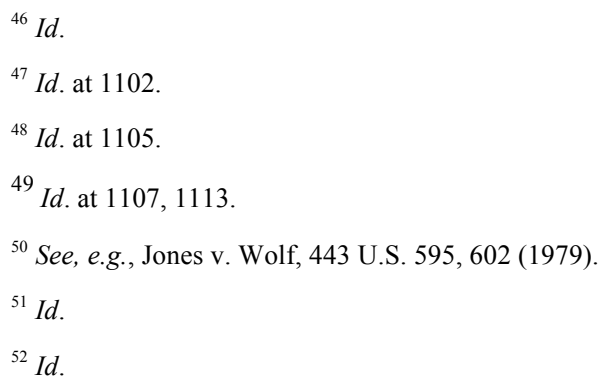


The Connor Court's neutral-principles approach, on the other hand, occurs before it applies any sort of deference rule. The Court frames the neutral-principles analysis as a test used to decide whether the Court is able to resolve the issues presented, thereby requiring the neutral-principles inquiry to happen before the deference inquiry. ${ }^{53}$ According to the Court's test, if there are sufficient neutral principles of law to prove each separate element of the claim at issue without entangling the trial court in religious issues, then there is no consideration of the deference rule whatsoever. ${ }^{54}$ If, however, there are not sufficient neutral principles on which the case may be decided, then the deference rule should apply. ${ }^{55}$ Such a reversal in the relationship of these two tests, as well as Connor's element-byelement approach, removes the strength from the deference rule that, since Watson, has provided strong protections for religious organizations. ${ }^{56}$

\section{LIFE AFTER CONNOR: THE EFFECT OF CONNOR ON Religious Disputes in Pennsylvania}

Two Pennsylvania court cases ${ }^{57}$ involving deference and neutral principles have applied Connor's new neutral-principles scheme. ${ }^{58}$ The decisions of these

${ }^{53}$ Connor, 975 A.2d at 1102.

${ }^{54}$ Id. at 1103 .

${ }^{55} I d$.

${ }^{56}$ Interestingly, Justice Powell's dissent in Jones v. Wolf anticipated this misapplication of the neutral principles doctrine. See Jones v. Wolf, 443 U.S. at 610-11 (Powell, J., dissenting). Justice Powell observed that the neutral principles approach was a departure from Watson and anticipated clearly that this new approach would inevitably cause an increase in civil court interference in religious affairs. See $i d$. In addition, Justice Powell points out that the neutral principles analysis turns the First Amendment inquiry on its head by limiting the "evidence" a court can consider, rather than considering the Free Exercise rights of the church:

The neutral-principles approach appears to assume that the requirements of the Constitution will be satisfied if civil courts are forbidden to consider certain types of evidence. The First Amendment's Religion Clauses, however, are meant to protect churches and their members from civil law interference, not to protect the courts from having to decide difficult evidentiary questions .... The neutral-principles approach consists instead of a rule of evidence that ensures in some cases the courts will impose a form of government and a doctrinal resolution at odds with that reached by the church's own authority.

Id. at 612 n. 2 .

${ }^{57}$ Specifically, these are the only two reported cases since Connor as of the date of this article's publication. 
courts reflect the drastic changes that the Connor Court made to the method by which courts must determine whether the resolution of an issue involving religion infringes upon the religious organization's First Amendment rights. Specifically, both of these courts required an element-by-element neutral-principles analysis before the court would consider giving deference to the decisions of a religious organization. ${ }^{59}$ Both courts recognized Connor's reversal in the application order of the rules. ${ }^{60}$

\section{A. Mundie v. Christ United Church of Christ}

In Mundie v. Christ United Church of Christ, the superior court's required adherence to Connor's new neutral-principles analysis led to a result that would have been unheard of before Connor. ${ }^{61}$ In a minister's breach of contract case, the superior court upheld the ex-minister's right on remand to provide non-religious proof for each of the elements of his claims as part of their neutral-principles analysis. ${ }^{62}$

Reverend Mundie appealed from an order sustaining Christ United Church of Christ's preliminary objection and dismissing Appellant's breach of contract complaint for lack of subject matter jurisdiction. ${ }^{63}$ The superior court reversed and decided that the court could resolve the underlying issues in the religious matter. ${ }^{64}$

In Mundie, the Consistory of the Christ United Church of Christ decided to terminate the pastor's employment four months early and not grant his retirement. ${ }^{65}$ Since the Consistory's decision was allegedly contrary to church laws and to state

\footnotetext{
${ }^{58}$ See Mundie v. Christ United Church of Christ, 987 A.2d 794 (Pa. Super. Ct. 2009); Salem United Church of Christ v. Darcy, No. 387 C.D., slip op. (Pa. Commw. Ct. Dec. 8, 2009).

${ }^{59}$ See Mundie, 987 A.2d 794; Salem United, No. 387 C.D. 2009.

${ }^{60}$ See id. This causes some confusion in Salem (see infra). It seems that the court has considered the issue and wants to grant deference to the decision of the church body regarding its minister. Showing such deference would be in line with Watson and the Free Exercise clause. However, the court applied Connor and seemingly recognized that Connor reversed the order of inquiry. Because of this reversal, the Salem Court cannot grant deference yet, but must remand the case for a neutral principles analysis.

${ }^{61} I d$.

${ }^{62} I d$. at 802 . This result is especially surprising in the context of the ministerial exception, a doctrine which usually provides greater protection to religious entities than the deference rule. See discussion infra Part IV.B.

${ }^{63} I d$. at 795 .

${ }^{64} \mathrm{Id}$.

${ }^{65} I d$. at 797.
} 
U N I V E R S I T Y O F P I T T S B U R G H L A W R E V I E W

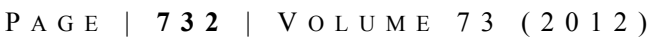

contract laws, Mundie filed claims of breach of contract and bad faith against the church. ${ }^{66}$ The trial court granted the church's preliminary objection, agreeing that the trial court could not resolve the contract issue because the dispute was ecclesial in nature. ${ }^{67}$ Mundie appealed, claiming that the "underlying dispute (breach of contract) does not turn on religious doctrine or polity but seeks the enforcement of a secular right through civil contract law." 68

To decide whether the trial court could resolve the issues present in this case, the superior court conducted a neutral-principles analysis. ${ }^{69}$ The court explained that the church had the right to "hire, fire, promote, and assign duties to its ministers as it sees fit, not because the churches are exempt from all employment regulations (for they are not) but rather because judicial review of those particular employment actions could interfere with rights guaranteed by the First Amendment." the court should decide whether it can be resolved without intruding into ecclesiastical matters. ${ }^{71}$ The Mundie Court's understanding of Connor's new neutral-principles analysis led to its conclusion that the appellant minister

should be allowed to demonstrate that he can prove his case [charging Appellee with breaching their oral promise] without resorting to impermissible avenues of discovery or remedies. Maintaining a suit, by itself will not necessarily create an excessive entanglement .... Furthermore, as the remedy would be limited to the award of money damages, we see no potential for the distortion of church appointment decisions requiring that the [Appellee] Church not make empty, misleading promises to its clergy. ${ }^{72}$

\footnotetext{
${ }^{66} I d$.

${ }^{67} I d$.

${ }^{68} I d$.

${ }^{69} I d$.

${ }^{70} I d$. at 798 .

${ }^{71}$ Id. at $799-800$.

${ }^{72}$ Id. at 801 (quoting Minker v. Baltimore Annual Conference of United Methodist Church, 894 F.2d 1354 (D.C. Cir. 1990)). Interestingly, the Mundie Court also recalled and applied the difference in desired remedy factor that Connor used to distinguish itself from Gaston. See id.; Connor v. Archdiocese of Philadelphia, 975 A.2d 1084, 1101-02 (Pa. 2009). Both Connor and Mundie asserted that money damages awarded in certain situations do not overly entangle the civil courts in religious
} 
In effect, because of Connor's new approach to determining which religious issues may be resolved by Pennsylvania courts, the superior court's inquiry asked merely if the elements of the claim could be proven by non-religious means, rather than asking whether deference should be given to this religious organization's decision regarding its pastor because of the religious organization's First Amendment rights.

\section{B. Salem United Church of Christ v. Darcy}

The Connor decision's reversal of the order in applying deference and neutral principles also led to an unusual result in the Pennsylvania Commonwealth Court. ${ }^{73}$ While the court knew that deference would normally be required in the case of a church's decision regarding its own minister, ${ }^{74}$ the court was unwilling to grant deference prematurely, and instead remanded the case for an element-by-element neutral-principles analysis consistent with the Connor opinion. ${ }^{75}$

The Salem United Church of Christ appealed from the order of the Court of Common Pleas denying and dismissing its complaint and petition for preliminary injunction. ${ }^{76}$ The Commonwealth Court vacated and remanded. ${ }^{77}$ Darcy was a member and pastor at Salem from 1988 until 2008, when the members voted to terminate her pastorship because of doubts about her pastoral abilities. ${ }^{78}$ When Darcy refused to accept her termination and continued to assert her position, Salem filed a complaint for an injunction. ${ }^{79}$ Darcy argued that the trial court could not resolve the underlying issues of the case without infringing upon the religious

decision-making, while equitable or injunctive relief or an order of specific performance in those same situations would produce entanglement. Mundie, 987 A.2d at 801; Connor, 975 A.2d at 1101-02.

73 Salem United Church of Christ v. Darcy, No. 387 C.D. 2009 (Pa. Commw. Ct. Dec. 8, 2009).

74 For a discussion of this specific form of deference referred to as the "ministerial exception," see infra Part IV.B.

${ }^{75}$ Salem United, No. 387 C.D. 2009, slip op. at 7.

${ }^{76} I d$. at 1 .

${ }^{77}$ Id.

${ }^{78} I d$. at 2 .

${ }^{79} I d$. at 1. Even after she was removed as pastor, Darcy continued to enter upon the premises of Salem, purporting to still be the minister. The congregation sought an injunction barring her from the church building, since she refused to respect their decision. Id. at 2-3. 
U N I V E R S I T Y O F P I T T S B U R G H L A W R E V I E W

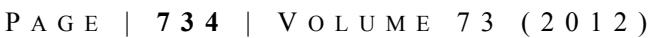

organization's First Amendment rights, while Salem answered that its complaint was a simple trespass action. ${ }^{80}$

The Commonwealth Court agreed with Salem. ${ }^{81}$ While acknowledging with Beaver-Butler the deference that courts must generally give the decisions of religious organizations in the resolution of internal religious matters, the court was reluctant to grant such deference prematurely. ${ }^{82}$ Citing Connor, the court held that an "in depth analysis of the substance of the claims set forth in a complaint" was necessary before a preliminary injunction could be granted. ${ }^{83}$ The court explained that

The trial court's dismissal of Salem's complaint and petition for injunction immediately after the settlement conference and prior to a hearing ... was error. Darcy had not even formally raised any defenses to Salem's complaint and petition for injunction and clearly the trial court did not conduct an analysis of the complaint on a claim by claim basis. As our Supreme Court has noted, all disputes among members of a congregation are not doctrinal disputes; deference is not mandated simply because there exists a judicature in the church. See Connor; Beaver-Butler. Therefore, this matter must be remanded to the trial court for proceedings consistent with the Supreme Court's holding in Connor. ${ }^{84}$

Again, in order to follow Connor, the trial court must turn the constitutional inquiry on its head. The court must first determine that no neutral principles of law with which the issue can be resolved exist before it can grant deference.

\section{LESSONS FROM HOSANNA-TABOR: APPLYING THE FIRST Amendment Religion Clauses}

Since the adoption of the First Amendment religion clauses, courts have had extreme difficulty in their attempts to articulate and apply workable analyses that uphold both the religious liberty of a religious organization and the rights granted to individuals in secular society. ${ }^{85}$ Some solutions have already been attempted,

${ }^{80} I d$.

${ }^{81} I d$. at 8 .

${ }^{82} I d$.

${ }^{83} \mathrm{Id}$. at 10.

${ }^{84} \mathrm{Id}$. at $10-11$.

${ }^{85}$ Among many other works, see, for example, BARRY ADAMSON, FREEDOM OF RELIGION, THE FIRST Amendment, And the Supreme Court: How the Court Flunked History (2008); Robin D. 
while many others have been proposed as preferable alternatives. ${ }^{86}$ Recently, the United States Supreme Court addressed this issue in a similar factual context in Hosanna-Tabor Evangelical Lutheran Church and School v. EEOC.$^{87}$ Examining the method by which the Supreme Court addressed the interplay between the right of religious freedom of religious organizations and individual's right of redress for civil wrongs sheds light upon interplay between the deference rule and the neutralprinciples analysis.

\section{A. Factual Background}

Hosanna-Tabor arose out of teacher Cheryl Perich's employment and subsequent termination of employment with Hosanna-Tabor Evangelical Lutheran Church and School ("Hosanna-Tabor"). ${ }^{88}$ Hosanna-Tabor describes its school as providing a "Christ-centered education" that helps parents by "reinforcing bible principals [sic] and standards." 89 Hosanna-Tabor describes its teachers as "fine

BARNES, NATURE AND SCOPE OF INDIVIDUAL RightS: EMERGING DEBATES IN CONSTITUTIONAL LAW (2008); THE FrEE EXERCISE OF RELIGION ClAUSE, supra note 16.

${ }^{86}$ See, e.g., Douglas Laycock, Church Autonomy Conference: Federalist Society Conference: "The Things That Are Not Caesar's: Religious Organizations as a Check on the Authoritarian Pretensions of the State”: Church Autonomy Revisited, 7 GEO. J.L. \& PUB. POL'Y 253 (2009). See also Ira C. Lupa \& Robert Tuttle, Giannella Lecture: The Distinctive Place of Religious Entities in Our Constitutional Order, 47 VILL. L. REV. 37 (2002).

One proposed alternative to the present tests is what is termed the "religious question" doctrine. See Jared A. Goldstein, Is There a "Religious Question" Doctrine? Judicial Authority to Examine Religious Practices and Beliefs, 54 CATH. U. L. REV. 497 (2005), for a full discussion of this approach; see also Frederick Mark Gedicks, Toward a Constitutional Jurisprudence of Religious Group Rights, 1989 WIS. L. REV. 99 (1989). Proponents of this understanding of civil courts' interaction with church disputes have noted a distinctive likeness between the courts' treatment of religious jurisdictional issues and the political question doctrine. See Goldstein, supra, at 499. See also Gedicks, supra, at 132; Idleman, supra note 8 , at 220 . While such a comparison on the surface seems apt, its functionality as a usable standard is questionable. Goldstein, supra, at 501. Like the neutral principles analysis, the "religious question" solution approaches the constitutional concerns from the wrong angle. See Idleman, supra note 8, at 252-55, 259-67. The proper application of the Free Exercise and Establishment Clauses is not analogous to a separation of powers issue; nor does it compare to the court's determination that this question would best be left to the jurisdiction of another party. See id. The Free Exercise Clause is not couched in such discretionary terms; rather, its purpose is the protection of religion and the convenience of "manageable standards" should have no bearing on whether religion will be protected. See id.

${ }^{87} 132$ S. Ct. 694 (2012).

${ }^{88}$ See id.

${ }^{89}$ EEOC v. Hosanna-Tabor Evangelical Lutheran Church \& Sch., 597 F.3d 769, 772 (6th Cir. 2010), rev'd, 132 S. Ct. 694 (2012). 
Christian role models who integrate faith into all subjects." ${ }^{\text {90 }}$ Perich enjoyed the opportunity to "bring God into every subject taught in the classroom." 11

Hosanna-Tabor's kindergarten-through-eighth-grade school employs two categories of teachers: "contract" teachers and "called" teachers. ${ }^{92}$ HosannaTabor's Board of Education hires contract teachers for renewable one-year periods, while the voting members of the Hosanna-Tabor church congregation hire called teachers on an open-ended basis. ${ }^{93}$ All called teachers must complete a colloquy of religious classes and receive a certificate of admission into the teaching ministry. ${ }^{94}$ Once selected by the congregation, the called teacher's title is that of "commissioned minister." ${ }^{95}$ Hosanna-Tabor hired Perich as a contract teacher for one year until she completed the required colloquy of courses, whereupon Hosanna-Tabor hired Perich as a called teacher and placed Perich's name on the list of commissioned ministers. ${ }^{96}$ Hosanna-Tabor employed Perich as a called teacher until her termination five years later. ${ }^{97}$

As both a lay and a called teacher, Perich taught secular classes using secular books for approximately six hours and fifteen minutes each day. ${ }^{98}$ In addition, each day Perich taught a religion class for thirty minutes and led classroom prayer three times a day. ${ }^{99}$ Once a week, Perich attended a thirty-minute chapel service with her class, and approximately twice a year Perich led the weekly chapel service. ${ }^{100}$

In June 2004, Perich unexpectedly became ill. ${ }^{101}$ When Perich's illness remained undiagnosed in August 2004, she accepted Hosanna-Tabor's suggestion that she take a disability leave of absence and did not return to her teaching

\footnotetext{
${ }^{90} I d$. at $772-73$.

${ }^{91} I d$. at 773.

${ }^{92} I d$. at 772 .

${ }^{93}$ Id.

${ }^{94}$ Id.

${ }^{95} \mathrm{Id}$.

${ }^{96}$ Id.

${ }^{97} \mathrm{Id}$. at 775 .

${ }^{98}$ Id. at 772.

${ }^{99}$ Id.

${ }^{100} \mathrm{Id}$.

${ }^{101}$ Id. at 773 .
} 
position at the beginning of the 2004-2005 school year. ${ }^{102}$ Hosanna-Tabor attempted to remedy Perich's absence by combining classes but ultimately had to hire a contract teacher in early January for the remainder of the 2004-2005 school year. ${ }^{103}$

On December 16, 2004, Perich informed Hosanna-Tabor that her physician had diagnosed her illness as narcolepsy and that she should be able to return to work in two to three months. ${ }^{104}$ Perich then informed Hosanna-Tabor that she would be able to return to work between February 14 and February 28, 2005. ${ }^{105}$ Hosanna-Tabor expressed various concerns about her early return to Perich, including Hosanna-Tabor's inability to break its contract with Perich's newly-hired replacement. ${ }^{106}$ On February 8, 2005, Perich's doctor gave her a written release to return to work on February 22, 2005, which Perich presented to Hosanna-Tabor at a board meeting on February 13, 2005. ${ }^{107}$ Hosanna-Tabor continued to express concerns about Perich's health and their ability to find a place for her by February $22 .{ }^{108}$ Perich informed the Board that, with the doctor's note, she was no longer eligible for disability coverage and would be required to return to work. ${ }^{109}$ Hosanna-Tabor offered Perich a "peaceful release" of her call in exchange for payment of a portion of her medical bills, but Perich rejected this offer. ${ }^{110}$

Perich reported to work on February 22, 2005, although Hosanna-Tabor had not yet found a position for her. ${ }^{111}$ Later that day, Perich informed Hosanna-Tabor that she would assert her legal rights against discrimination if they were unable to reach a compromise. ${ }^{12}$ On February 22, 2005, Hosanna-Tabor sent Perich a letter indicating that the Board would review the process of rescinding her call because of her "regrettable" disruptive behavior, and followed up on March 19 with a letter

$$
\begin{aligned}
& { }^{102} I d \text {. } \\
& { }^{103} I d \text {. at } 773 \text { n. } 1 \text {. } \\
& { }^{104} I d \text {. at } 773 \text {. } \\
& { }^{105} I d \text {. } \\
& { }^{106} I d \text {. } \\
& { }^{107} I d \text {. at } 774 \text {. } \\
& { }^{108} I d \text {. } \\
& { }^{109} I d \text {. } \\
& { }^{110} I d \text {. } \\
& { }^{111} I d \text {. } \\
& { }^{112} I d \text {. }
\end{aligned}
$$


U N I V E R S I T Y O F P I T T S B U R G H L A W R E V I E W

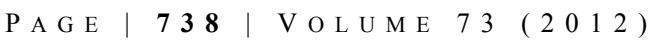

informing Perich that, due to her insubordination and disruptive behavior, the Board would request rescinding Perich's call at the next voter's meeting. ${ }^{113}$ Perich's attorney again expressed that Perich planned to bring a lawsuit or file a complaint with the EEOC ${ }^{114}$ and Hosanna-Tabor's congregation voted to rescind Perich's call. $^{115}$

\section{B. The Ministerial Exception and Its Connection with the Deference Rule}

The ministerial exception arises out of the deference-rule tradition and is in fact the application of the deference rule in a specific circumstance- the selection by a religious organization of its leaders or "ministers." "In Kedroff v. St. Nicholas Cathedral, the Supreme Court specifically ruled that religious organizations have a First Amendment right to select their own religious leaders, stating that the "freedom to select the clergy ... must now be said to have constitutional protection as a part of the free exercise of religion against state interference."117

The Supreme Court has consistently upheld this principle that religious organizations must be free to choose their own religious leaders. In the 1976 Supreme Court case Serbian Eastern Orthodox Diocese for the U.S. \& Canadav. Milivojevich, ${ }^{118}$ the Court refused to review the Serbian Eastern Orthodox Church's defrocking of a bishop, stating that "it is the function of the church authorities to determine what the essential qualifications of a chaplain are and whether the candidate possesses them."

\footnotetext{
${ }^{113} I d$.

${ }^{114} I d$. at 775 .

${ }^{115} I d$.

${ }^{116}$ See Kedroff v. St. Nicholas Cathedral of Russian Orthodox Church in N. Am., 344 U.S. 94 (1952).

${ }^{117} I d$. at 116 .

${ }^{118} 426$ U.S. 696 (1976).

${ }^{119}$ Id. at 711 (citing Gonzalez v. Roman Catholic Archbishop of Manila, 280 U.S. 1, 16 (1929)).
} 


\section{The U.S. Supreme Court's First Amendment Analysis in Hosanna-Tabor ${ }^{120}$}

In Hosanna-Tabor, the Court was seemingly faced with the choice to either allow a religious organization the latitude and flexibility to disobey antidiscrimination laws at will, or to infringe upon this religious organization's constitutionally guaranteed First Amendment rights. ${ }^{121}$ The ministerial exception, which was designed to protect the rights of religious organizations, could be a vehicle by which religious individuals' anti-discrimination rights are ignored by the courts. However, when looking back upon the long line of cases establishing and developing the court's attitude toward religions and their leaders, it seems that the function of the ministerial exception, in effect, is to ensure that whoever is in a position of authority, education, or representation is chosen by that religious organization, using their own doctrinally acceptable criteria.

Chief Justice Roberts delivered the opinion of a unanimous Court, reversing the Sixth Circuit, and upholding the district court's grant of summary judgment to Hosanna-Tabor. ${ }^{122}$ The Chief Justice, beginning with a discussion of the Magna Carta and continuing to the adoption of the First Amendment, outlined the history of the struggle for freedom from government interference with religion, a struggle which formed the background of the adoption of the First Amendment. ${ }^{123}$ Based on this history and the intent of the First Amendment religion clauses as illustrated by the writings and actions of the founding fathers, the Court upheld the ministerial exception. ${ }^{124}$ In strong support of the First Amendment freedoms afforded religious organizations, the Court stated that

[r] equiring a church to accept or retain an unwanted minister, or punishing a church for failing to do so, intrudes upon more than a mere employment decision. Such action interferes with the internal governance of the church, depriving the church of control over the selection of those who will personify its beliefs. By imposing an unwanted minister, the state infringes the Free Exercise

\footnotetext{
${ }^{120}$ A large part of the inquiry in Hosanna-Tabor involved whether the Court would establish a rule determining which people or positions within a religious institutions qualify as "ministers" under the ministerial exception. See Hosanna-Tabor Evangelical Lutheran Church \& Sch. v. EEOC, 132 S. Ct. 694 (2012). The bulk of that argument is not addressed within the scope of this article.

${ }^{121}$ See id.

${ }^{122} I d$. at 710 .

${ }^{123}$ Id. at $702-03$.

${ }^{124} \mathrm{Id}$. at 706.
} 
U N I V E R S I T Y O F P I T T S B U R G H L A W R E V I E W

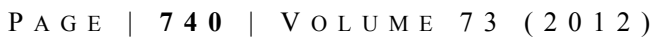

Clause, which protects a religious group's right to shape its own faith and mission through its appointments. According the state the power to determine which individuals will minister to the faithful also violates the Establishment Clause, which prohibits government involvement in such ecclesiastical decisions. $^{125}$

Further, the Court emphasized that "government interference with an internal church decision that affects the faith and mission of the church itself" is a distinct area requiring protection under the First Amendment religion clauses. ${ }^{126}$

\section{Hosanna-Tabor and Connor: Lessons in Interpreting the Religion Clauses}

Given the U.S. Supreme Court's long history and recent reaffirmation of the importance of allowing religious organizations the freedom to shape its mission and doctrine, the Pennsylvania Supreme Court's narrowing of these freedoms seems to conflict with the profound amount of respect and deference with which the United States Supreme Court has consistently interpreted these clauses.

In addition to interpreting the First Amendment religion clauses broadly, the Court also-as is illustrated in Hosanna-Tabor-utilizes a purpose-driven interpretation of these clauses. That is, the Court re-articulates the background and purpose behind the adoption of the First Amendment religion clauses, and seeks to uphold this purpose through its ruling. The Court, in essence, considers the effect of its ruling on the freedoms of the religious organizations in question, rather than employing mechanical tests or more narrow inquiries.

It is precisely this inquiry into the effect of a judicial determination of a certain issue on a religious organization's First Amendment rights that the deference rule is meant to address. ${ }^{127}$ However, it is this very effect, or purpose, inquiry that is lacking in Connor and its progeny. When the neutral-principles analysis occurs prior to, and instead of, the application of the deference rule, the question of what effect such a decision will have on a religious organization remains unasked. The neutral-principles analysis merely establishes whether a court has sufficient non-doctrinal evidence with which it can decide a certain issue, and fails to ask the deference-rule question of whether the court can decide the issue, considering the religious organization's First Amendment rights.

\footnotetext{
${ }^{125} \mathrm{Id}$.

${ }^{126} I d$. at 697.

${ }^{127}$ See Watson v. Jones, 80 U.S. 679, 729 (1871).
} 
For example, one of the subsequent Pennsylvania cases discussed earlier, Mundie v. Christ United Church of Christ, involved the employment contract of a religious leader in a religious organization. ${ }^{128}$ According to Hosanna-Tabor, the first appropriate inquiry should have been a deference-rule analysis, and specifically the more precise analysis of whether the ministerial exception should apply. ${ }^{129}$ Instead of applying any type of deference or ministerial exception examination, the Mundie Court conducted a neutral-principles analysis and determined that the minister should have the opportunity to demonstrate that he could prove his breach of contract claims without "resorting to impermissible avenues of discovery or remedies." ${ }^{130}$ This approach to the deference and neutralprinciples analysis never reaches the question asked by the ministerial exception and the deference rule, namely, whether a court's interference in a religious matter would impermissibly impinge upon the religious organization's First Amendment religious freedoms.

\section{Conclusion}

Watson v. Jones first established the common-law basis for the deference rule in response to the Constitution's explicit support of the free exercise of religion. Watson assumed that having the authority to decide its own affairs was a determinative requirement that religious organizations and their members must possess to be considered free. ${ }^{131}$ The United States Supreme Court has continued its support of the rights afforded to religious organizations by the First Amendment religion clauses, most recently reaffirming its commitment in a unanimous 2012 decision. ${ }^{132}$

${ }^{128} 987$ A.2d 794 (Pa. Super. Ct. 2009).

${ }^{129}$ See Hosanna-Tabor, 132 S. Ct. at 705-06.

${ }^{130}$ Mundie, 987 A.2d at 801.

${ }^{131}$ See Watson v. Jones, 80 U.S. at 728-29:

In this country the full and free right to ... practice any religious principle ... is conceded to all.... It is the essence of these religious unions, and of their right to establish tribunals for the decision of questions arising among themselves, that those decisions should be binding all cases of ecclesiastical cognizance....

Id. In addition, the Watson Court stated that, if civil courts were to inquire into these religious matters, it "would deprive these bodies of the right of construing their own church laws" which "would open the way to all the evils which we have depicted as attendant upon the doctrine of Lord Eldon [the English tradition]." Id. at 733 .

${ }^{132}$ See Hosanna-Tabor, 132 S. Ct. 694. 
U N I V E R S I T Y O F P I T T S B U R G H L A W R E V I E W

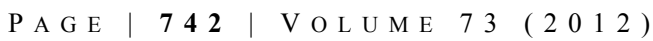

The deference rule and the neutral-principles analysis arose as separate and complementary inquiries. However, the Pennsylvania Supreme Court in Connor turns this relationship on its head by reversing the inquiry. ${ }^{133}$ The Connor analysis begins with its newly defined element-by-element neutral-principles inquiry. ${ }^{134}$ If each element - separately considered - can be decided with neutral principles of law, the inquiry ends and the deference rule is never applied. ${ }^{135}$

Such a skewed relationship between these tests results in the omission of the constitutional inquiry into the effect that the court's resolution of a certain issue would have on the First Amendment rights of the religious organization. In essence, this new neutral-principles scheme asks whether a court is able to resolve a certain issue, not whether it is constitutionally permissible for a court to do so.

The United States Supreme Court's recent decision in Hosanna-Tabor sheds light on an appropriate approach to determining which issues affecting religious organizations may be resolved by the court without infringing upon the organization's First Amendment rights. ${ }^{136}$ The key lies in a careful consideration of the overall effect that any decision may have on a religious organization's determination of its members, leaders, tenets, or doctrine. The Hosanna-Tabor court upholds the deference rule in the specific form of the ministerial exception. ${ }^{137}$ Lastly, Hosanna-Tabor reminds courts that the purpose of the First Amendmentensuring religious liberty and preventing the oppression of religion — should be the fundamental goal of all courts.

${ }^{133}$ See Connor v. Archdiocese of Philadelphia, 975 A.2d 1084 (Pa. 2009).

${ }^{134}$ See id.

${ }^{135}$ See id.

${ }^{136}$ See Hosanna-Tabor, 132 S. Ct. 694.

${ }^{137}$ See id. 